\title{
MT1G wt Allele
}

National Cancer Institute

\section{Source}

National Cancer Institute. MT1G wt Allele. NCI Thesaurus. Code C105398.

Human MT1G wild-type allele is located in the vicinity of $16 q 13$ and is approximately $1 \mathrm{~kb}$ in length. This allele, which encodes metallothionein-1G protein, plays a role in both binding and transport of trace metals. 